\title{
Effect of Different Fertilizer Doses on Turmeric varieties under Poplar based Agroforestry System
}

\author{
Anil Kumar* and B. Mehera \\ College of Forestry, Sam Higginbottom University of Agriculture Technology \& Sciences \\ Allahabad-211 007, India \\ *Corresponding author
}

\section{A B S T R A C T}

\section{Keywords \\ Turmeric, Poplar, Fertilizer doses, Yield \\ Article Info \\ Accepted: \\ 24 January 2018 \\ Available Online: \\ 10 February 2018}

The field experimental study was conducted at Forest Nursery, College of Forestry, Sam Higginbottom University of Agriculture Technology and Sciences, Allahabad during 2014 - 2016 to evaluate the Turmeric (Curcuma Longa) varieties with different fertilizer doses under Poplar (Populus deltoids) based Agroforestry system. The experimental results observed in the present study at successive stage 225 DAS, application of $\mathrm{T}_{4}\left(\mathrm{C}_{1} \mathrm{~F}_{2}\right.$ Suvarna + Dose 60:50:120) produced significantly maximum plant height $(43.25 \mathrm{~cm})$, no. of leaves (20.720), yield per plant $(0.390 \mathrm{Kg})$ and total rhizome yield (6.385 tonns/ha.) in open condition as well as at successive stage 225 DAS, under poplar based Agroforestry system application of $\mathrm{T}_{4}\left(\mathrm{C}_{1} \mathrm{~F}_{2}\right.$ - Suvarna + Dose 60:50:120) produced significantly maximum plant height $(42.365 \mathrm{~cm})$, no. of leaves $(20.250)$, yield per plant $(0.350 \mathrm{Kg})$ and total rhizome yield (6.385tonns/ha.)

\section{Introduction}

Agro-forestry is a collective name for land-use systems in which woody perennials (trees, shrubs, etc.) are grown in association with herbaceous plants (crops, pastures) and livestock in a spatial arrangement, a rotation or both, and in which there are both ecological and economic interactions between the tree and non-tree components of the system. Through agroforestry is being practised in large parts of the country in one or another and has been adopted by the farmers in different agro-climatic zones, periodic estimation and monitoring of the area under it is still a challenging task due to lack of uniform methodology adopted by the different agencies 11. The current approximate area under agroforestry is estimated to be $25.32 \mathrm{~m}$ ha, or $8.2 \%$ of the total geographical area of the country. Based on data from CAFRI, Jhansi, the area under agroforestry is $13.75 \mathrm{~m}$ ha13. However, Forest Survey of India (FSI2013) estimated the same as $11.54 \mathrm{~m}$ ha, which is $3.39 \%$ of the geographical area of the country. Maharashtra, Gujarat and Rajasthan rank high in state-wise area under agroforestry. Poplars hold a place of great significance in India as they are among the most preferred tree species in unique agroforestry systems in northern part of the country. Six indigenous species of poplars, viz., Populus ciliate, $P$. alba, $P$. euphratica, $P$. gamblii, $P$. Jacquemontii var. glauca and $P$. 
rotundifolia are reported in India. Some experts consider $P$. alba and $P$. euphratica as exotics. $P$. deltoids has very high growth rate (mean annual increment of 20 to 25 $\mathrm{m}^{3} / \mathrm{ha} /$ year) in India.

The high productivity is achieved only when it is intercropped with such agricultural or horticultural crops as require intensive irrigation and other cultural operations. Research on agroforestry of this species was started by FRI Dehradun, Haldwani centre of state forest department and WIMCO in early 1960s. Cultivation of $P$. deltoides in agroforestry system by farmers started in 1970s; during early years it was practiced only by very rich and progressive farmers who had surplus land and financial power to bear the risk of plantation failure.

Turmeric (Curcuma longa l.) belongs to the Zingiberaceae family along with the noteworthy members like ginger, cardamom and galangal. It belongs to the genus Curcuma that consists of hundreds of species of plants that possess rhizomes and underground root like stems.

Turmeric is of special importance to humans with the discovery that its rhizomes powder, when added to various food preparations, preserves their freshness and imparts a characteristic flavour. Turmeric, which belongs to a group of aromatic species, had been originally used as a food additive in curries to improve the storage condition, palatability and preservation of food. Turmeric is grown in warm, rainy regions of the world (Jayaprakasha, et al., 2005).

\section{Materials and Methods}

The present study was carried out in Factorial RBD in Forest Nursery, College of Forestry, SHUATS, Allahabad (at an elevation of $25.41^{\circ} \mathrm{N}$ latitude and $81.84^{\circ} \mathrm{E}$ longitude, and
98 meter above the mean sea level.) Utter Pradesh, India. It is located in the Southeastern part of Uttar Pradesh and has tropical to sub-tropical climate with extremes of summer and winter. During the winter months especially December and January, temperature drops down to as low as $5^{\circ} \mathrm{C}$, while in the summer temperature reaches above $45^{\circ} \mathrm{C}$, hot scorching winds (commonly known as Loo) is regular feature during the summers whereas there may be an occasional spell of frost during the winter. The annual rainfall is 1100 mm mostly during the monsoon autumn i.e. July to September, with a few occasional showers during the winter months.

On the basis of field trial, field size is consisting of $108 \mathrm{~m}^{2}$ with three replications and nine treatments in association with Poplar (Populus deltoids) 15 years old, planted at $9 \times$ $9 \mathrm{~m}$ spacing were selected for the experiments of Turmeric (Curcuma longa). Planting materials was procured from local market of Allahabad (UP). Seed rhizomes may be put in shallow pits and covered with well rotten cattle manure or compost mixed with Trichoderma (10 gm compost inoculated with Trichoderma). A seed rate of $1000 \mathrm{~kg}$ rhizomes is required for planting one acre of land. The experiment was laid out during the last week of March. The planting bed of $2 \times 2$ $\mathrm{m}$ size was prepared and the distance kept for Curcuma longa was $20 \times 20 \mathrm{~cm}$ within and between rows $(5-10 \mathrm{~cm}$ depth). Similar spacing was kept for both row to row and plant to plant. The FYM (Farm Yard Manure), vermicompost, neemcake and leaf mould compost were added at the time of last ploughing and recommended dose of fertilizers were applied in the trial which was @ 60:50:120 kg NPK ha-1 for Curcuma longa. The rate was splitted in to three equal quantities and applied as a basal dose in March-April (Planting time), in July (vegetative stage) and in the last week of September (growth stage). 
Table.1 Plant Height (cm) of Turmeric (open \& under poplar) as influenced by different fertilizer doses under Poplar based Agroforestry system

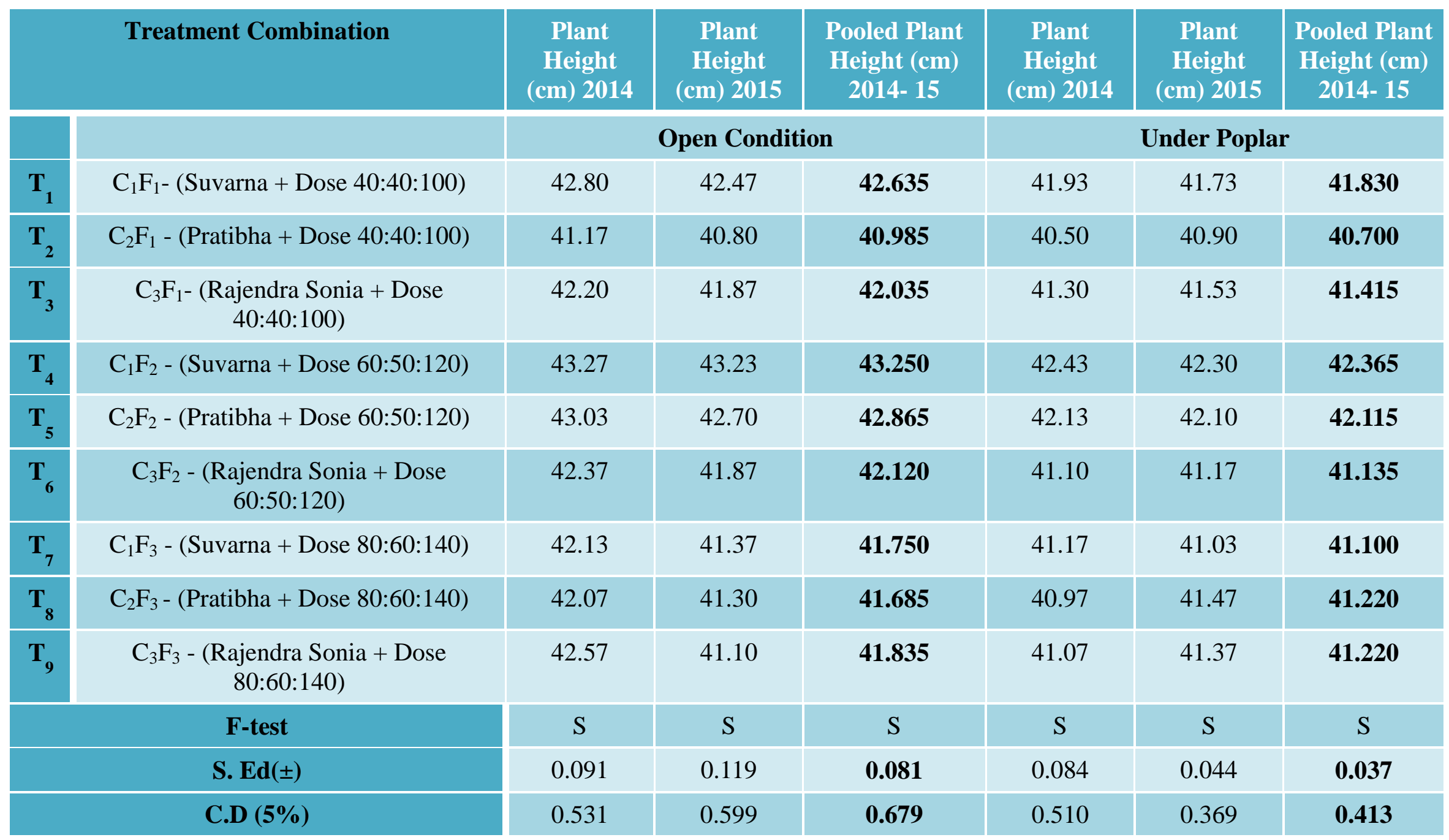

Method of Fertilizer application as Basal dressing. 
Table.2 No. of leaves of Turmeric (open \& under poplar) as influenced by different fertilizer doses under Poplar based Agroforestry system

\begin{tabular}{|c|c|c|c|c|c|c|c|}
\hline & Treatment Combination & $\begin{array}{c}\text { No. of } \\
\text { leaves } 2014\end{array}$ & $\begin{array}{c}\text { No. of } \\
\text { leaves } 2015\end{array}$ & $\begin{array}{c}\text { Pooled No. of } \\
\text { leaves } 2014 \text { - } \\
15\end{array}$ & $\begin{array}{c}\text { No. of } \\
\text { leaves } 2014\end{array}$ & $\begin{array}{c}\text { No. of } \\
\text { leaves } 2015\end{array}$ & $\begin{array}{l}\text { Pooled No. of } \\
\text { leaves 2014-15 }\end{array}$ \\
\hline & & & Open Cond & & & Under Pop & \\
\hline $\mathbf{T}_{1}$ & $\mathrm{C}_{1} \mathrm{~F}_{1^{-}}($Suvarna + Dose $40: 40: 100)$ & 20.07 & 20.07 & 20.070 & 19.57 & 19.90 & 19.735 \\
\hline $\mathbf{T}_{2}$ & $\mathrm{C}_{2} \mathrm{~F}_{1}-($ Pratibha + Dose $40: 40: 100)$ & 19.00 & 19.50 & 19.250 & 18.83 & 19.00 & 18.915 \\
\hline $\mathbf{T}_{3}$ & $\begin{array}{c}\mathrm{C}_{3} \mathrm{~F}_{1} \text { - (Rajendra Sonia }+ \text { Dose } \\
40: 40: 100)\end{array}$ & 19.73 & 19.90 & 19.815 & 19.27 & 19.70 & 19.485 \\
\hline $\mathbf{T}_{4}$ & $\mathrm{C}_{1} \mathrm{~F}_{2}-($ Suvarna + Dose 60:50:120) & 20.67 & 20.77 & 20.720 & 20.07 & 20.43 & 20.250 \\
\hline $\mathbf{T}_{5}$ & $\mathrm{C}_{2} \mathrm{~F}_{2}-($ Pratibha + Dose $60: 50: 120)$ & 20.33 & 20.63 & 20.480 & 19.90 & 20.20 & 20.050 \\
\hline$T_{6}$ & $\begin{array}{c}\mathrm{C}_{3} \mathrm{~F}_{2}-\text { (Rajendra Sonia }+ \text { Dose } \\
60: 50: 120)\end{array}$ & 19.87 & 19.80 & 19.835 & 19.50 & 19.23 & 19.365 \\
\hline $\mathbf{T}_{7}$ & $\mathrm{C}_{1} \mathrm{~F}_{3}-($ Suvarna + Dose $80: 60: 140)$ & 19.37 & 19.60 & 19.485 & 19.13 & 19.53 & 19.330 \\
\hline $\mathbf{T}_{\mathbf{8}}$ & $\mathrm{C}_{2} \mathrm{~F}_{3}-($ Pratibha + Dose 80:60:140) & 19.87 & 20.00 & 19.935 & 19.23 & 19.63 & 19.430 \\
\hline $\mathbf{T}_{9}$ & $\begin{array}{c}\mathrm{C}_{3} \mathrm{~F}_{3}-\text { (Rajendra Sonia + Dose } \\
\text { 80:60:140) }\end{array}$ & 19.33 & 20.00 & 19.665 & 19.03 & 19.87 & 19.450 \\
\hline & F-test & $\mathrm{S}$ & $\mathrm{S}$ & $\mathbf{S}$ & $\mathrm{S}$ & $\mathrm{S}$ & $\mathbf{S}$ \\
\hline & S. $\operatorname{Ed}( \pm)$ & 0.078 & 0.010 & 0.027 & 0.055 & 0.402 & 0.047 \\
\hline & C.D (5\%) & 0.480 & 0.178 & 0.384 & 0.402 & 0.390 & 0.479 \\
\hline
\end{tabular}

Method of Fertilizer application as Basal dressing. 
Table.3 Total rhizome yield of Turmeric (open \& under poplar) as influenced by different fertilizer doses under Poplar based Agroforestry system

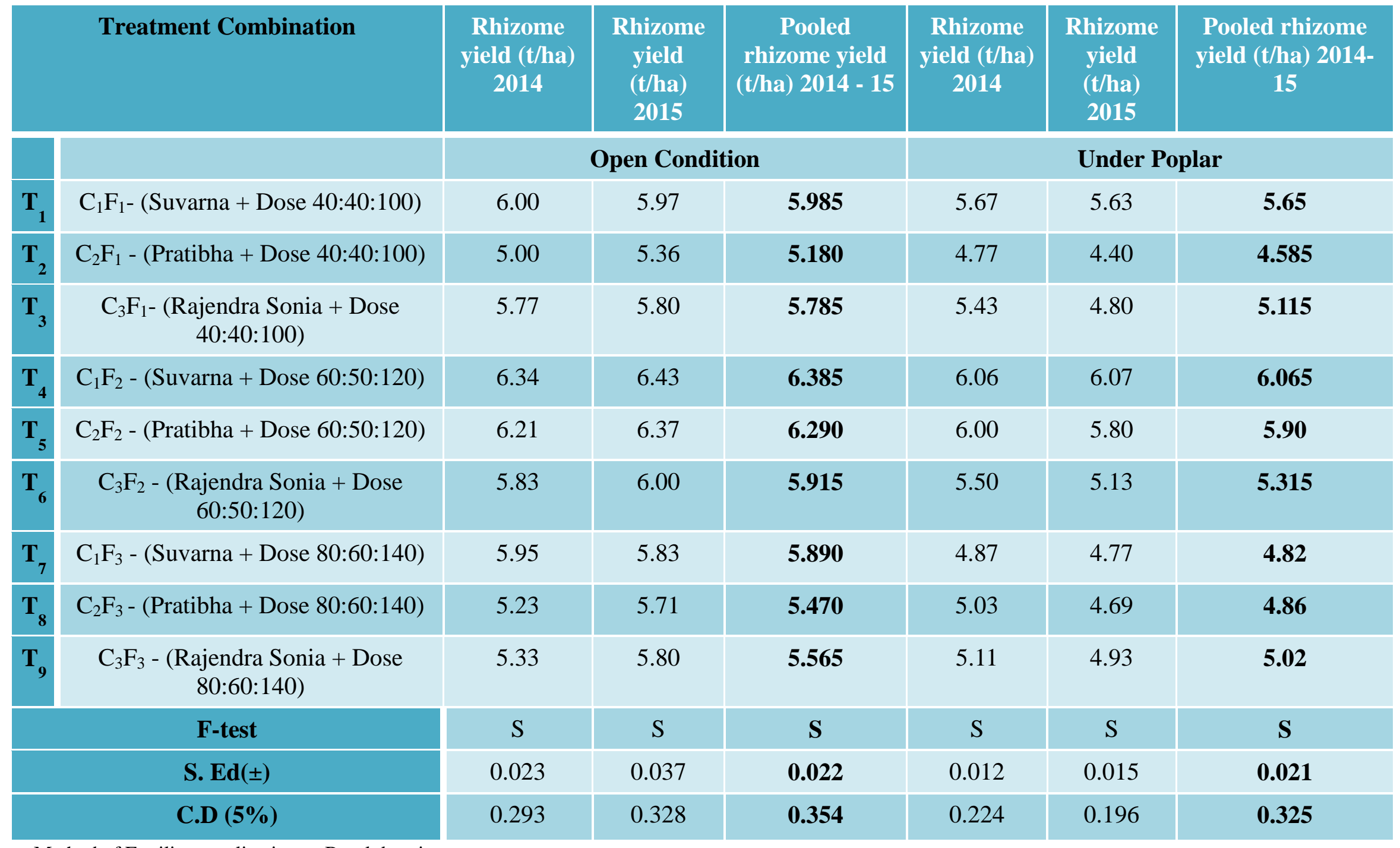

Method of Fertilizer application as Basal dressing. 


\section{Results and Discussion}

\section{Plant height}

There was a significant effect on the shoot height of Turmeric as affected by different fertilizer doses. Plant height was found to be progressively increased with the treatment $\mathrm{T}_{4}$ $\left(\mathrm{C}_{1} \mathrm{~F}_{2}\right.$ - Suvarna + Dose 60:50:120) compared to other fertilizer doses (Table 1). According to the pooled data of the year $2014-16$ maximum plant height was observed in $\mathrm{T}_{4}$ $(43.25 \mathrm{~cm})$ followed by $\mathrm{T}_{5}(42.865 \mathrm{~cm})$ and minimum plant height recorded in $\mathrm{T}_{2}(40.985$ $\mathrm{cm}$ ) in open area, whereas highest plant height was recorded in $\mathrm{T}_{4}(42.365 \mathrm{~cm})$ followed by $\mathrm{T}_{5}(42.115 \mathrm{~cm})$ and minimum plant height recorded in $\mathrm{T}_{2}(40.70 \mathrm{~cm})$ under Poplar.

Similar results were reported by Haque et al., 2007. There was a significant effect of different fertilizer doses on the growth and yield of Turmeric.

\section{No. of leaves}

There was a significant effect on no. of leaves of Turmeric as affected by different fertilizer doses. No. of leaves was recorded maximum with the treatment $\mathrm{T}_{4}\left(\mathrm{C}_{1} \mathrm{~F}_{2}-\right.$ Suvarna + Dose 60:50:120) compared to other fertilizer doses (Table 2).

According to the pooled data of the year 2014 -16 maximum no. of leaves was recorded in $\mathrm{T}_{4}$ (20.720) followed by $\mathrm{T}_{5}$ (20.480) and minimum no of leaves recorded in $\mathrm{T}_{2}(19.25)$ in open area, whereas under poplar maximum no of leaves was recorded in $\mathrm{T}_{4}(20.250)$ followed by $\mathrm{T}_{5}(20.050)$ and minimum no of leaves recorded in $\mathrm{T}_{2}$ (18.915). Similar results were reported by Satyareddi and Angadi 2014. There was a significant effect of different fertilizer doses on no. of leaves of Turmeric.

\section{Yield of turmeric}

Data revealed that in two years pooled data of various treatment combinations, there was significant effect on yield per plot (tonns/ha.) in open condition and under Poplar. The maximum yield per plot was observed in $\mathrm{T}_{4}$ (6.385 tonns/ha.) followed by $\mathrm{T}_{5}(6.290$ tonns/ha.) while minimum yield per plot was recorded in $\mathrm{T}_{2}$ (5.180 tonns/ha.) in the open condition. Whereas, under Poplar maximum yield per plot was observed in $\mathrm{T}_{4}(6.065$ tonns/ha.) followed by $\mathrm{T}_{5}$ (5.90 tonns/ha.) while minimum yield per plot was recorded in $\mathrm{T}_{2}$ (4.585 tonns/ha.) respectively (Table 3). Similar results were reported by Satyareddi and Angadi 2014. There was a significant effect of different fertilizer doses on the total rhizome yield of Turmeric.

In view of the experimental results observed in the present study, application of $\mathrm{T}_{4}\left(\mathrm{C}_{1} \mathrm{~F}_{2}\right.$ Suvarna + Dose 60:50:120) produced significantly maximum plant height, no. of leaves and yield in Turmeric followed by $\mathrm{T}_{5}$ $\left(\mathrm{C}_{2} \mathrm{~F}_{2}\right.$-Pratibha + Dose 60:50:120) as comparison to other fertilizer doses (dose 40:40:100 \& dose 80:60:140). So it may be concluded that it is economically dose 60:50:120 $\left(\mathrm{T}_{4}\right)$ with Suvarna is the best combination for the production of Turmeric under Poplar based agroforestry system but before giving final recommendations, multilocation trials should be conducted with this treatment combinations as far as planting condition concerned.

\section{References}

Gormus, O. 2002. Yield response of cotton to foliar fertilization of potassium in Cukurova Region. Turkish. J. Field crops. 9(1):1 35-42.

Haque M. M., Rahman A. K. M. M., Ahmed M., Masud M. M. and Sarker M. M. R. 2007. Effect of Nitrogen and Potassium 
on the Yield and Quality of Turmeric in Hill Slope. Int. J. Sustain. Crop Prod. 2(6):10-14.

Jayaprakasha, G. K., Jaganmohan Rao, L., \& Sakariah, K. K. (2002). Improved HPLC method for the determination of curcumin, demethoxycurcumin, and bisdemethoxycurcumin. Journal of Agricultural and Food Chemistry, 50, 3668-3672.

Jayaprakasha, G. K., Jena, B. S., Negi, P. S., \& Sakariah, K. K. (2002). Evaluation of antioxidant activities and antimutagenicity of turmeric oil - a byproduct from curcumin production. Zeitschrift fur Naturforschung, 57c, 828-835.

Jayaprakasha, K.M., G. K., Jagan Mohan Rao, L., \& Sakariah, K. K. (2004). Jaganmohan antioxidant activities of flavidin in different in vitro model systems. Bioorganic and Medicinal
Chemistry, 12, 5141-5146.

Krishnan, P. K. and Christopher L.A., 1997. Different levels time and method of application of nitrogen and potash on the uptake of nutrients and soil nutrients status in cotton. Madras Agricultural J. 84:2 330-334.

Mayilsamy, R. and Iruthayaraj, M. R. 1980. Effect of plant density and $\mathrm{N}$ application on the uptake of major nutrient by cotton. Madras Agril. J. 67:1 484-490.

Mohsin, R. Khan, H. Tahir, M. Hussain, M. and Shah, S. 2004. Effect of different combinations of $\mathrm{N} \mathrm{P} \mathrm{K}$ growth and yield of seed cotton variety CIM-443. Sarhad Agril. 20(1):11-4.

Sunil A. Satyareddi and S. S. Angadi 2014: Response of turmeric (Curcuma longa L.) varieties to irrigation methods and graded levels of fertilizer. Res. Environ. Life Sci. 7(4) 237- 242 (2014).

\section{How to cite this article:}

Anil Kumar and Mehera, B. 2018. Effect of Different Fertilizer Doses on Turmeric varieties under Poplar based Agroforestry System. Int.J.Curr.Microbiol.App.Sci. 7(02): 2739-2745. doi: https://doi.org/10.20546/ijcmas.2018.702.333 